\section{Soil and Thatch Microbial Populations in an $80 \%$ Sand : 20\% Peat Creeping Bentgrass Putting Green}

\author{
Charles F. Mancino ${ }^{1}$, Mohammad Barakat ${ }^{2}$, and Alison Maricic ${ }^{3}$ \\ Department of Plant Sciences, University of Arizona, Tucson, AZ 85721
}

Additional index words. Agrostis palustris, turfgrass, fungi, actinomycetes, aerobes, nitrate reducers, nitrite reducers, microbial respiration

\begin{abstract}
This study examined the numbers of specific soil and thatch microbial populations in a U.S. Golf Association (USGA) specification sand-peat putting green of creeping bentgrass (Agrostis palustris Huds.) over 17 months. Changes caused by adding a water-soluble or bio-organic (water-insoluble, contains microbial inoculum) $\mathbf{N}$ source were examined. Thatch was found to contain 40 to 1600 times as many bacteria as the soil, 500 to 600 times as many fungi, and up to 100 times as many actinomycetes. Soil populations of nitrate- and nitrite-reducing anaerobes were similar and ranged from $10^{3}$ to $10^{5}$ per gram of dry soil. Adding the bio-organic $\mathrm{N}$ source increased soil fungal counts and thatch thickness when compared with the control (no $\mathrm{N}$ applied), but not as much as the water-soluble $\mathrm{N}$ source. The amendments had no effect on soil respiration, total organic carbon. or total $\mathbf{N}$ content.
\end{abstract}

Modem golf course putting green soils typically are comprised of sand-peat mixtures specified by the U.S. Golf Association (USGA) (Ferguson, 1965). Although information is available on the microflora of native turfgrass soils and thatch, little, if any, is available for artificial soil mixtures, despite the fact that soil and thatch microbes perform many beneficial activities. These activities include the accumulation and decomposition of organic matter, and nutrient availability and recycling (Alexander, 1977). Cole and Turgeon (1978) reported that soil and thatch of Kentucky bluegrass (Poa pratensis L.) turf can contain 1.8 to $280 \times 10^{6}$ bacteria, 5.7 to $9.3 \times 10^{6}$ actinomycetes, and 0.1 to $2.8 \times 10^{6}$ fungi per gram of dry soil, thatch, or both. Mancino and Torello (1986) reported that populations of bacteria capable of reducing $\mathrm{NO}_{3}$ and $\mathrm{NO}_{2}$ in a Kentucky bluegrass turf ranged from 1.0 to $94.4 \times 10^{4}$ per gram of dry soil; higher populations were associated with saturated soil conditions and heavier soil textures. A sandy soil generally contains lower populations of microflora and microfauna than heavier soils because the clay and organic soil fractions, which are higher in heavier soils, are mostly responsible for a soil's biological properties (Alexander, 1977). The overlying thatch layer likely contains more microbes than a sandpeat soil because it provides a moist environ-

Received for publication 4 Feb. 1992. Accepted for publication 19 Oct. 1992. Research conducted at the Univ. of Arizona Rincon Vista Turfgrass Facility, Tucson. Use of trade names does not imply endorsement of the products named nor criticism of similar ones not named. The cost of publishing this paper was defrayed in part by the payment of page charges. Under postal regulations, this paper therefore must be hereby marked advertisement solely to indicate this fact.

${ }^{1}$ Assistant Professor

${ }^{2}$ Former Graduate Research Assistant.

${ }^{3}$ Research Assistant. ment containing readily available substrates, such as cellulose and hemicellulose.

Thatch also contains lignin, which is not readily decomposed by soil microbes (Alexander, 1977; Lederboer and Skogley, 1967; Martin and Dale, 1980; Starkey, 1953). Excessive thatch accumulation can be detrimental to turfgrass and typically is controlled through verticutting and top-dressing (Beard, 1973). Attempts are being made to develop turf amendments that can control thatch biologically. These bio-organic amendments may contain one or more organic forms of $\mathrm{C}$ and $\mathrm{N}$, enzymes, and various microbes. The usefulness of these amendments in controlling thatch remains unclear (Berndt et al., 1990; Martin and Beard, 1975; Murdoch and Barr, 1976; Sartain and Volk, 1984).

The objectives of this project were to determine 1) the number of specific microbial populations in a 'Penncross' creeping bentgrass sand-peat putting green soil and the overlying thatch layer, and 2) the influence of adding a water-soluble N source and the Greens Restore (Ringer Corp., Minneapolis) bio-organic amendment on microbial counts and soil $\mathrm{pH}$, total organic carbon (TOC), total nitrogen (TN), and respiration.

The study was initiated on 20 Mar. 1989 on a 1.3-year-old 'Penncross' creeping bentgrass putting green that was constructed according to USGA specifications (Ferguson, 1965) and on which no previous research had been conducted. The experiment's site was at the Univ. of Arizona Rincon Vista Turfgrass Facility, Tucson. The rootzone mixture was $80 \%$ sand : $20 \%$ peat (v/v) with a $0.9 \%$ TOC content. The grass was mowed three times per week to a height of $1.3 \mathrm{~cm}$, clippings were removed, and the putting green was irrigated as necessary to prevent wilting.

The $\mathrm{N}$ treatments consisted of a watersoluble source $(21 \mathrm{~N}-7 \mathrm{P}-14 \mathrm{~K})$, the water-insoluble Greens Restore N source (47C-6N), and no $\mathrm{N}$ (control). Nitrogen was applied at $28.5 \mathrm{~kg} \cdot \mathrm{ha}^{-1}$ on 20 Mar., 19 May, 11 July, 12 Sept., and 16 Nov. 1989; and 9 Jan., 20 Mar., 7 May, 5 June, 8 July, and 7 Aug. 1990. In addition to $\mathrm{C}$ and $\mathrm{N}$, Greens Restore contained an inoculum of Bacillus sp., Saccharomyces sp., and Trichoderma sp. Exact composition of Greens Restore was proprietary information of Ringer Corp. There were four replications per treatment in a randomized completeblock design on $9-\mathrm{m}^{2}$ plots.

Soil and thatch sampling. Samples were collected just before each treatment application, except the first. Table 1 shows the dates in which soil and thatch characteristics were measured. At each sampling date, 10 soil and thatch cores were collected from each plot with a 25-mm-diameter soil sampler and trimmed to a soil depth of $76 \mathrm{~mm}$. Compressed thatch thickness was measured in millimeters with a ruler after the core was compressed lightly along its long axis by fingertip. Thatch thickness of the 10 subsamples from an experimental unit was averaged. The thatch layer was then separated from the underlying soil, sealed in a plastic bag, and stored at $4.5 \mathrm{C}$ until analyzed $24 \mathrm{~h}$ later. The soil cores from each plot were then cornposited, sieved $(\leq 2 \mathrm{~mm})$, stored for $24 \mathrm{~h}$ at $4.5 \mathrm{C}$, and analyzed for microbes.

Microbial populations. A 5-g soil subsample was taken from each experimental unit; placed in sterile, distilled saline solution $(45 \mathrm{ml}, 0.85 \% \mathrm{NaCl})$; and thoroughly shaken for 2 min. A 10-fold dilution series was carried out to $10^{-9}$. Aliquots $(0.5 \mathrm{ml})$ of the $10^{-5}$ to $10^{-9}$ dilutions were spread on petri dishes containing soy-tryptic broth (Difco Bacto tryptone; Difco, Detroit) for total aerobic bacteria, peptone-glucose agar $\left(1.0 \mathrm{~g} \mathrm{KH}_{2} \mathrm{PO}_{4}, 0.5 \mathrm{~g}\right.$ $\mathrm{MgSO}_{4}, 5.0 \mathrm{~g}$ peptone, $10.0 \mathrm{~g}$ glucose, and $20.0 \mathrm{~g}$ agar in 1.0 liter distilled $\mathrm{H}_{2} \mathrm{O}$ adjusted to $\mathrm{pH} 3.8$ with $\mathrm{H}_{2} \mathrm{SO}_{4}$ following autoclaving) for fungi, and sodium caseinate-containing agar (Difco actinomycete isolation agar) for actinomycetes. Plates were incubated for 7 days in darkness at $28 \mathrm{C}$. The dilution yielding 50 to 100 colonies was selected for plate counts. The number of microbes per gram of oven-dried soil was then calculated. Microbes were counted in thatch samples ( $5.0 \mathrm{~g}$ fresh weight) in a manner similar to that used on the soil and their numbers reported on a per-gram-drythatch basis.

The number of soil microbes capable of reducing $\mathrm{NO}$; or NO; under anaerobic conditions was determined from 5-g soil subsamples that represented a composite of the four replicates of a treatment at a sampling time (Table 1). The microtiter most-probable-number (MPN) procedure outlined by Staley and Griffin (1981) was used to count these populations. However, $\mathrm{NO}_{3}$ and $\mathrm{NO}_{2}$ broths, each 9.9 $\mathrm{mM}$, were contained in separate microtiter plates (Volz, 1977b). The soil subsamples were diluted using the lo-fold serial dilution procedure noted above. Aliquots $(50 \mu \mathrm{l})$ of the $10^{-2}$ to $10^{-9}$ dilutions were used to inoculate the microtiter wells, each of which contained 50 $\mu \mathrm{l}$ of broth. Each 96-well microtiter plate had 12 replications of each of the eight dilutions. 


\begin{tabular}{|c|c|c|c|c|c|c|c|c|c|c|c|c|c|}
\hline \multirow[b]{2}{*}{ Date } & \multicolumn{2}{|c|}{ Bacteria } & \multicolumn{2}{|c|}{ Fungi } & \multicolumn{2}{|c|}{ Actinomycetes } & \multicolumn{2}{|c|}{$\begin{array}{l}\text { Amaeruvic } \\
\text { N reducers }\end{array}$} & \multicolumn{4}{|c|}{ Soil } & \multirow[b]{2}{*}{ CTT $^{x}$} \\
\hline & Soil & Thatch & Soil & Thatch & Soil & Thatch & $\mathrm{NO}_{3}^{-}$ & $\mathrm{NO}_{2}^{-}$ & $\mathbf{R}^{z}$ & $\mathrm{pH}$ & $\mathrm{N}$ & TOC $^{y}$ & \\
\hline & & & & & & 1989 & & & & & & & \\
\hline 19 May & $t^{w}$ & + & $\mathrm{NM}^{\mathrm{v}}$ & $\mathrm{NM}$ & $\mathrm{NM}$ & $\mathrm{NM}$ & + & NM & NM & + & + & + & + \\
\hline 11 July & + & + & NM & NM & NM & NM & + & NM & NM & + & + & + & NM \\
\hline 12 Sept. & + & + & NM & NM & NM & NM & + & + & NM & + & + & + & + \\
\hline 16 Nov. & + & + & + & NM & + & $\begin{array}{l}\text { NM } \\
1990\end{array}$ & + & + & + & + & + & + & + \\
\hline 9 Janı. & + & + & + & + & + & + & + & + & + & NM & NM & NM & + \\
\hline 20 Mar. & + & + & + & + & + & + & + & + & + & + & + & + & + \\
\hline 7 May & + & + & + & + & + & + & + & + & NM & NM & NM & NM & + \\
\hline 5 June & + & + & + & + & + & + & + & + & + & + & + & + & + \\
\hline 8 July & + & + & + & + & + & + & + & + & + & NM & NM & NM & + \\
\hline 7 Aug. & + & + & + & + & + & + & + & + & + & NM & NM & NM & + \\
\hline 8 Sept. & + & + & + & + & + & + & + & + & + & + & + & + & + \\
\hline
\end{tabular}

${ }^{2} \mathrm{R}=$ respiration.

YTOC $=$ total organic carbon

${ }^{\mathrm{x}} \mathrm{CTT}=$ compressed thatch thickness .

"Measured.

'NM = not measured.

Plates were then placed in a battery jar with an air-tight lid. The jar's headspace was flushed with $\mathrm{N}_{2}$ gas through an opening in the lid to create an anaerobic environment. Samples were incubated for 7 days at 30C, and each well was tested for the presence of NO; using Morgan's reagent, or $\mathrm{NO}_{2}$ using NEDD reagent, depending on the original $\mathrm{N}$ substrate in the broth (Staley and Griffin, 1981). Wells not containing $\mathrm{N}$ were scored positive for the presence of anaerobic $\mathrm{N}$ reducers. The MPN $( \pm 95 \%$ confidence interval) for each treatment and time was calculated using a computerized statistical package (Hurley and Roscoe, 1983).

Soil microbial respiration. The soda-lime method was used to measure soil microbial respiration (Edwards, 1982). Cornposited 30g soil samples from each plot were placed in $473-\mathrm{ml}$ mason jars and brought to $30 \%$ of saturation with $6 \mathrm{ml}$ distilled water. A $20 \mathrm{gg}$ sample of oven-dried (100C for $24 \mathrm{~h}$ ) sodalime 80-mesh $\mathrm{NaOH}+\mathrm{CaO}$ ) contained in an open weighing boat was suspended inside each mason jar, which was then tightly sealed and incubated for 7 days at 30C. A vial with 5 $\mathrm{ml}$ distilled water also was suspended inside each jar to maintain constant humidity during incubation. After incubation, the soda-lime was oven-dried and reweighed again. Increase in soda-lime weight was due to trapped $\mathrm{CO}$, produced by microbial respiration.

Soil $\mathrm{pH}, T O C$, and TN. Soil $\mathrm{pH}$ was determined on a 1 soil : 1 water (v/v) extract using a solution analyzer (model 5800-05; ColeParmer Instrument Co., Chicago). TOC and $\mathrm{TN}$ were determined by the combustion method and chromatographic gas-type separation using the NA $1500 \mathrm{C}-\mathrm{N}-\mathrm{S}$ analyzer at the Soil, Water and Plant Testing Lab., Dept. of Soil and Water Sciences, Univ. of Arizona.

Statistical analysis. Because seasonal variations in soil and thatch characteristics were beyond the scope of the objectives, analysis of variance was performed using SAS's GLM procedure (SAS, 1988) on pooled measurements over time; $\mathrm{N}$ treatments served as main plots. Soil and thatch data were analyzed sepa- rately. Microbial populations were analyzed statistically using log-transformed data.

Treatment effect. Thatch thickness and soil fungal counts were the only variables affected by $\mathrm{N}$ treatments (Table 2). Water-soluble $\mathrm{N}$ treated plots had the thickest thatch, while nonfertilized controls had the thinnest. Differences in thatch thickness may be attributed to the amount of readily available $\mathrm{N}$ applied. Meinhold et al. (1973) and Potter et al. (1985) found that applying increasing $\mathrm{N}$ levels increased lignin production and thatch accumulation. In our study, all of the applied water-soluble $\mathrm{N}$, but only $1 \%$ of $\mathrm{N}$ in Greens Restore, was readily available.

Initially, we thought that Greens Restore might decrease thatch thickness due to the microbial inoculum it contained. Berndt et al. (1990) found that applying inoculated bioorganic amendments to Kentucky bluegrass turf on a native soil reduced thatch thickness. They suggested that the decreased thatch thickness could have been caused by the increased number of earthworms found in the Lawn Restore (Ringer Corp.)-treated plots. Our putting green contained no earthworms, and thatch accumulated despite the fact that Greens Restore delivered the same inoculum as Lawn Restore. Murdoch and Barr (1976) did not find the bio-organic amendments Bio-dethatch and Thatch-Away effective in reducing thatch thickness of bermudagrass golf tees. The influence of $\mathrm{N}$ source on soil fungi in our study remains unexplained (Table 2).

Table 2. Effect of $\mathrm{N}$ source on soil and thatch characteristics in an $80 \%$ sand : $20 \%$ peat (v/v) creeping bentgrass putting green $(n=$ number of total observations for the mean).

\begin{tabular}{|c|c|c|c|c|}
\hline \multirow[b]{2}{*}{ Characteristic } & \multirow[b]{2}{*}{$\mathbf{n}$} & \multicolumn{3}{|c|}{$\mathrm{N}_{\text {source }}{ }^{2}$} \\
\hline & & Water-soluble & Greens Restore & None \\
\hline \multicolumn{5}{|c|}{ Total aerobic bacteriay } \\
\hline Soil & 44 & $5.4 \mathrm{a}^{\mathrm{x}}$ & $5.5 \mathrm{a}$ & $5.6 a$ \\
\hline Thatch & 44 & $8.1 \mathrm{a}$ & $8.0 \mathrm{a}$ & $8.0 \mathrm{a}$ \\
\hline \multicolumn{5}{|l|}{ Fungi $^{y}$} \\
\hline Soil & 32 & $1.9 \mathrm{a}$ & $1.5 \mathrm{ab}$ & $1.1 \mathrm{~b}$ \\
\hline Thatch & 28 & $5.1 \mathrm{a}$ & $5.1 \mathrm{a}$ & $4.8 \mathrm{a}$ \\
\hline \multicolumn{5}{|l|}{ Actinomycetes ${ }^{y}$} \\
\hline Soil & 32 & $3.2 \mathbf{a}$ & $3.1 \mathrm{a}$ & $3.3 \mathrm{a}$ \\
\hline Thatch & 28 & $4.6 \mathrm{a}$ & $4.9 \mathrm{a}$ & $4.4 \mathrm{a}$ \\
\hline \multicolumn{5}{|c|}{ Anaerobic $\mathrm{N}$ reducers ${ }^{y}$} \\
\hline $\mathrm{NO}_{3}^{-}$ & 11 & $3.6 \mathrm{a}$ & $3.7 \mathrm{a}$ & $3.3 \mathrm{a}$ \\
\hline $\mathrm{NO}_{2}^{-}$ & 9 & $4.0 \mathrm{a}$ & $3.5 \mathrm{a}$ & $4.0 \mathrm{a}$ \\
\hline \multicolumn{5}{|l|}{ Soil } \\
\hline Respirationw & 28 & $6.7 \mathrm{a}$ & $6.2 \mathrm{a}$ & $6.4 \mathrm{a}$ \\
\hline $\mathrm{pH}$ & 7 & $7.8 \mathbf{a}$ & $7.8 \mathrm{a}$ & $7.8 \mathrm{a}$ \\
\hline $\operatorname{TOC}^{\mathrm{v}}(\%)$ & 7 & $1.2 \mathrm{a}$ & $1.2 \mathrm{a}$ & $1.2 \mathrm{a}$ \\
\hline $\mathrm{TN}^{\mathrm{u}}(\%)$ & 7 & $0.07 \mathrm{a}$ & $0.08 \mathrm{a}$ & $0.07 \mathrm{a}$ \\
\hline \multicolumn{5}{|l|}{ Compressed thatch } \\
\hline thickness (mm) & 40 & $7.8 \mathrm{a}$ & $7.4 \mathrm{~b}$ & $7.0 \mathrm{c}$ \\
\hline
\end{tabular}

${ }^{2}$ Water-soluble (21N-7P-14K) and Greens Restore (6N-1P-3K) N applied at $28.5 \mathrm{~kg}^{-h^{-1}}$ every 60 days from May 1989 to May 1990 and every 30 days from June to Sept. 1990. Controls received no N.

${ }^{y_{L} \operatorname{Lg}_{10}}$ per gram of dry sample.

"Mean separation in rows determined by LSD, $P \leq 0.05$.

${ }^{\text {wRespiration }}=$ micrograms $\left(\times 10^{3}\right) \mathrm{CO}_{2}$ per gram of dry soil over 7 days.

TOC $=$ total organic carbon.

"TN = total nitrogen. 


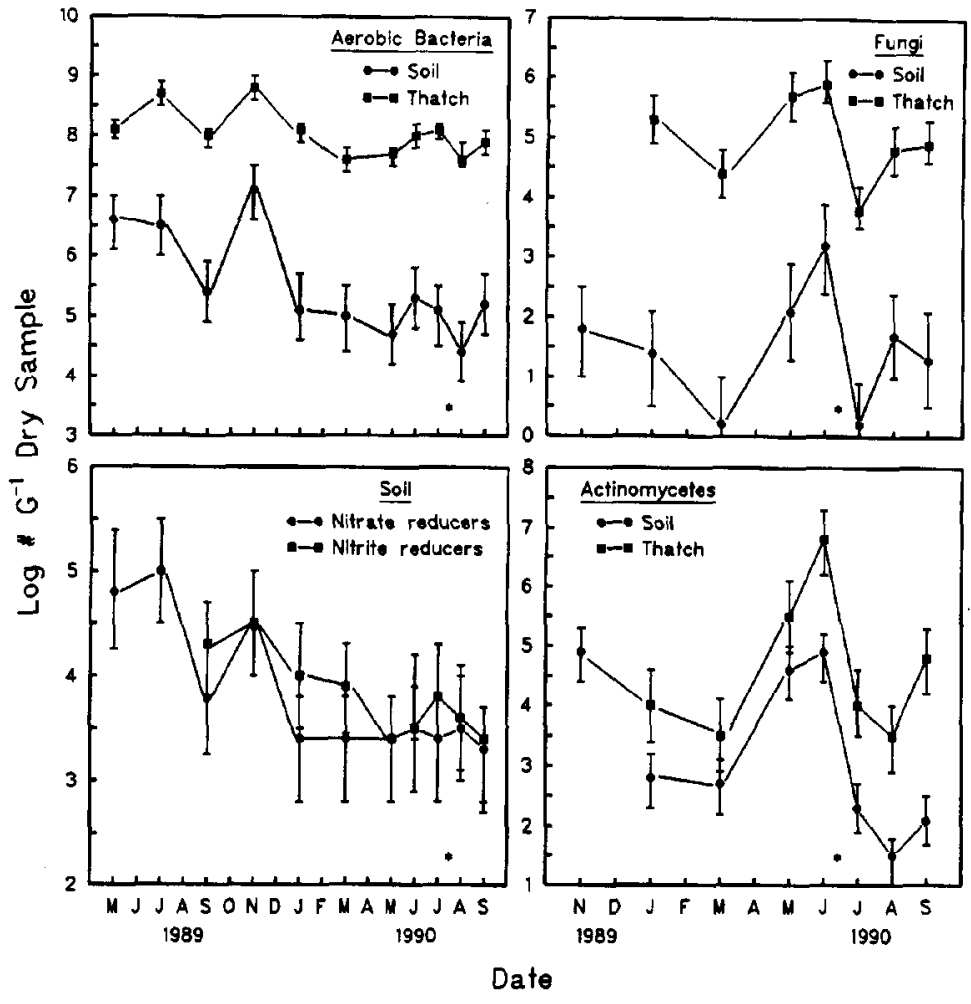

Fig. 1. Number of soil and thatch microbes in an $80 \%$ sand : $20 \%$ peat (v/v) 'Penncross' creeping bentgrass putting green. Bars represent SE, except for nitrate and nitrite reducers, for which bars represent $\pm 95 \%$ confidence interval. Asterisk indicates time of fungicide application.

Microbial populations. Bentgrass thatch contained fairly high levels of bacteria (Table 2). This result indicated that the thatch was a more suitable environment for bacteria than the underlying sand-peat soil because it provided more favorable environmental conditions ( $\mathrm{pH}$, moisture, substrate availability) or a greater surface area on which the bacteria could grow. Thatch contained 40 to 1600 times as many bacteria as the soil, depending on the sampling date (Fig. 1). The overall bacterial populations in this soil and thatch were higher than those reported by Smiley and Craven (1979) in their soil plus thatch mixture, possibly because their samples contained only small quantities of thatch.

Fungal counts in thatch were 500 to 1600 times higher than in the sand-peat soil, depending on sampling date (Fig. 1). Soil fungi counts often were low and sometimes approached zero (Mar. and July 1990). By combining the number of fungi found in the thatch and soil, we achieved populations similar to those reported for Kentucky bluegrass sod on native soils (Cole and Turgeon, 1978; Smiley and Craven, 1979). However, our sand-peat soil only slightly contributed to the overall population.

The number of $\mathrm{NO}_{3}$ and $\mathrm{NO}_{2}$ reducers in this putting green soil each ranged from $\approx 10^{3}$ to $10^{5}$ (Fig. 1), depending on sampling time, and represented a small percentage of the total aerobic bacterial population (Table 2). The number of reducers reported in this sand-peat mixture are at the low end of the ranges reported by others for more heavily textured soils (Focht and Joseph, 1973; Mancino and
Torello, 1986; Volz, 1977a, 1977b). Although the presence of bacteria capable of reducing $\mathrm{NO}_{3}$ and $\mathrm{NO}_{2}$ does not imply their activity, it serves as an index of a population capable of denitrifying the $\mathrm{N}$ that is available to plants (Davidson et al., 1985). Mancino et al. (1988) showed that denitrification could increase substantially in a turfgrass soil previously determined to contain a large denitrifying population (Mancino and Torello, 1986).

Similar to bacteria and fungi populations, actinomycete populations were higher in thatch than in the soil (Fig. 1). However, the numbers of actinomycetes in thatch and soil were more similar than those of bacteria and fungi.

Sand-peat putting greens apparently can contain microbial populations as high as those found in some native soils. However, in our study, the overlying thatch layer clearly accounted for most of these microbes, particularly fungi. The sand-peat soil mixture contained few microorganisms capable of reducing $\mathrm{NO}_{3}^{-}$and $\mathrm{NO}_{2}$ under anaerobic conditions. This lack may indicate that a small potential for denitrification exists, but this possibility could be verified only by directly measuring denitrification. Using Greens Restore to increase the counts of thatch bacteria, fungi, and actinomycetes and decrease thatch thickness does not seem useful because of the already high levels of indigenous thatch microbes.

\section{Literature Cited}

Alexander, M. 1977. Introduction to soil microbiology. 2nd ed. Wiley, New York.

Beard, J.B. 1973. Turfgrass: Science and culture. Prentice-Hall, Englewood Cliffs, NJ.
Berndt, W.L., P.E. Rieke, and J.M. Vargas, Jr. 1990. Kentucky bluegrass thatch characteristics following application of bio-organic materials. HortScience 25:412-414.

Cole, M.A. and A.J. Turgeon. 1978. Microbial activity in soil and litter underlying bandane- and calcium arsenate-treated turfgrass. Soil Biol. Biochem. 10:181-186.

Davidson, E.A., M.K. Strand, and L.F. Galloway. 1985. Most probable number method for enumerating denitrifying bacteria. Soil Sci. Soc. Amer. J. 49:642-645.

Edwards, N.T. 1982. The use of soda-lime for measuring respiration rates in terrestrial systems. Pedobiology 23:325-330.

Ferguson, M.H. 1965. After five years: The Green Section specification for a putting green. USGA Green Section Record 3(4):1-7.

Focht, D.D. and H. Joseph. 1973. An improved method for the enumeration of denitrifying bacteria. Proc. Soil Sci. Soc. Amer. 37:698-699.

Hurley, M.A. and M.E. Roscoe. 1983. Automated statistical analysis of microbial enumeration by dilution series. J. Applied Bacteriol. 55:159164.

Lederboer, F.B. and C.R. Skogley. 1967. Investigations into the nature of thatch and methods for its decomposition. Agron. J. 59:320-323.

Mancino, C.F. and W.A. Torello. 1986. Enumeration of denitrifying microbial populations in turf. Plant \& Soil 96: 149-15 1.

Mancino, C.F., W.A. Torello, and D.J. Wehner. 1988. Denitrification losses from Kentucky bluegrass sod. Agron. J. 80:148-153.

Martin, D.P. and J.B. Beard. 1975. Procedure for evaluating the biological degradation of turfgrass thatch. Agron. J. 67:835-836.

Martin, S.B. and J.L. Dale. 1980. Biodegradation of turf thatch with wood-decay fungi. Dis. Control Pest Mgt. 70(4):297-300.

Meinhold, V.H., R.L. Duble, R.W. Weaver, and E.C. Holt. 1973. Thatch accumulation in bermudagrass turf in relation to management. Agron. J. 65:833-835.

Murdoch, C.L. and J.P. Barr. 1976. Ineffectiveness of commercial microorganism inoculum in breaking down thatch in common bermudagrass in Hawaii. HortScience 11:488-489.

Potter, D.A., B.L. Bridges, and F.C. Gordon. 1985. Effect of $\mathrm{N}$ fertilization on earthworm and microarthropod populations in Kentucky bluegrass turf. Agron. J. 77:367-372.

Sartain, J.B. and B.G.Volk. 1984. The influences of selected white rot fungi and topdressings on the composition of thatch components of four turfgrasses. Agron. J. 76:359-362.

SAS Institute. 1988. SAS user's guide. The GLM procedure. SAS Inst., Cary, N.C.

Smiley, R.W. and M.M. Craven. 1979. Microflora of turfgrass treated with fungicides. Soil Biol. Biochem. 11:349-353.

Staley, T.E. and J.B. Griffin. 1981. Simultaneous enumeration of denitrifying and nitrate reducing bacteria in soil by a microtiter most-probablenumber (MPN) procedure. Soil Biol. Biochem. 13:385-388.

Starkey, R.L. 1953. Relations of microorganisms to control thatch in turf. Golf Course Rptr. 21(7):9 14.

Volz, M.G. 1977a. Assessing two diagnostic methods for enumeration of nitrate reducing and denitrifying bacteria in soil-plant associations. Soil Sci. Soc. Amer. J. 41:337-340.

Volz, M.G. 1977b. Denitrifying bacteria can be enumerated in nitrite broth. Soil Sci. Soc. Amer. J. 41:549-551 